Article

\title{
In Defence of Plant Personhood
}

\author{
Matthew Hall[D
}

Victoria University of Wellington, Kelburn Parade, Wellington 6023, New Zealand; matt.hall@vuw.ac.nz

Received: 21 March 2019; Accepted: 3 May 2019; Published: 10 May 2019

\begin{abstract}
The philosopher Michael Marder has asserted that animist engagement with plants involves a projection of human purposes and goals leading to veneration. He has also argued that an extension of a categorical concept of personhood underpins my previous work on plant personhood. This paper draws on the growing scholarship of animist traditions following the work of Hallowell to reject Marder's characterization of a naïve animist approach to plants. It draws on these insights from animist traditions to outline a relational plant personhood, which is fully realized only in grounded, situated relationships of care that seek to enable the flourishing of plants.
\end{abstract}

Keywords: plants; personhood; animism; kinship; relational autonomy; ethics; care; subjectivity

\section{Introduction}

The geographer Puleo (2019) has recently charted the ever-increasing body of research into plant subjectivities. Starting his journey with Michael Pollan's The Botany of Desire, Puleo navigates through the work of Stefano Mancuso, a pioneer of plant neurobiology, name checks this author's work on plant personhood and explores Michael Marder's vegetal ontology alongside Jeffrey Nealon's work on plant theory. Of particular interest to this author, and to this Special Issue on religions and plants, is Marder's criticism of the concept of plant personhood. In a discussion of plants as subjects, Puleo cites Marder's assertion in his work Plant-Thinking (Marder 2013, p. 55), that in attributing concepts of autonomy or personhood to plants, philosophers "render more refined the violence human thought has never ceased unleashing against these beings ... ", and connects this with another rejection of the concept of personhood by the plant biologist Daniel Chamovitz. Puleo dips his toe into an analysis of competing depictions of plant life, contrasting the idea of personhood with Marder's attempt to emphasise the radical alterity of plant being. He presented Marder's view of plant ontology as "so radically different from that of humans, that words such as persons, subjectivity and self cannot be applied. Indeed, to call a plant a person is an insult" (Puleo 2019, p. 224).

A view of plant ontology in which you can insult a plant by calling it a person stems from Marder's philosophy of plant thinking. According to Marder (2013, p. 43), "plant thinking starts with the explosion of identity", that is, following Derrida's deconstruction of "the animal", plants are regarded as multiplicitous assemblages, modularly composed of parts capable of independent rejuvenation. The plant is not a differentiated organism, but a collection of many. Therefore "if the plant is not an organism consisting of interdependent organs, we should avoid conceiving it as atolity or as a differentiated whole" (Marder 2013, p. 84). This assertion of non-identity is intimately connected with a lack of "interiority", presented as such both because plants do not (on the whole) consume other organisms, but also because plants, as generally sessile, are rooted in place and, according to Marder (2013, p. 107), completely open to their environment, a "sheer exposure in space and time." Therefore, for Marder (2013, p. 89), "Given that the plant's self, bound to the universality of the elements and of light, is always external to itself, its unity is at once a disunity ... ."

For Marder, the clearest symptom of this non-identity of the plant is its "unrest", a restless, intentional growth and plasticity, a "ceaseless striving towards the other and becoming-other in 
growth and reproduction, as well as in the metamorphosis of these vegetal qualities into human and animal potentialities" (Marder 2013, p. 162). Marder connects this "ceaseless growth" and ontological openness with the "generosity" of plant life. Therefore to "attribute a static identity is to disregard this vivacity" (Marder 2013, p. 162). Indeed, to pay heed to a vegetal non-identity is to also acknowledge vegetal "ontological indifference", which (Marder 2013, pp. 133-35) exemplifies through the plant "selflessly" throwing away its pollen, fruits and seeds. The acknowledged "ontic" (material) facts of plants possessing self-defence mechanisms do not deter this argument.

Marder's deconstruction of plant ontology renders the plant as a non-autonomous, self-less, non-identity, indifferent, non-organism. I will argue directly against these claims in a later paper. Here, I wish to focus on his dismissal of personhood.

To do so, I wish to highlight two further claims by Marder. The first of these arises in his discussion of the "fetishism" of plants in his book Plant-Thinking (Marder 2013). Here, Marder rejects what he called "animist mentalities", which find something "inexplicable and miraculous" in the plant and therefore treat it as "worthy of veneration" and whose myths are found to be "paving the way for the projection of human purposes and goals onto it." (Marder 2013, p. 29). The second claim, published in a journal article titled 'Is it Ethical to Eat Plants?', is worth quoting.

The problematic assumption that the concept of personhood can be extended to plants underpins Matthew Hall's recent book, Plants as Persons: A Philosophical Botany ... (Marder 2013, p. 37)

There are in fact three sub-claims here: that my book Plants as Persons (Hall 2011) assumes that a categorical personhood can be extended to plants, that this underpins the work, and that such an idea is problematic. Marder does not expand on the latter claim, but from the treatment of "plant fetishism", I assume that he regarded personhood as a human-centred projection based on an obfuscation, sublimation or eradication of a plant's nature. This, also presumably, is at the heart of the alleged violence toward plants that Puleo (2019) charts.

The purpose of this article is to reject Marder's claims about the animist understandings of plants and of the concept of plant personhood as it appears in my previous work. Such endeavours are interlinked, as in Plants as Persons, I draw deeply on the concepts of personhood found in animist cultures. With a simple purpose, the structure of this article will also be fairly straightforward. I will very briefly sketch out the broad categories of personhood, as they have been employed in Western philosophy, to help situate the animistic personhood that Marder both mischaracterises and with which he takes offence. I will explore the work of leading scholars in the study of animism, to understand how relational personhood works, before outlining how such ideas have shaped my own notion of plant personhood. We will close with a brief discussion of how the relationships of care that personhood requires can be effected without recourse to philosophical violence.

\section{Approaches to Personhood}

First, it will be useful to outline the general landscape with regards to the concept of personhood. Even the briefest of dips into the literature illustrate that there are a myriad of claims to the concept. Thankfully, there is also plenty of existing scholarship that can provide an overarching view of how the concept has been deployed, without copious detail distracting us from our central purpose. Here, I will draw on the recent work of Foster and Herring $(2017 \mathrm{a}, 2017 \mathrm{~b})$, which provides a broad categorisation of the existing theories of personhood and will fill a couple of noticeable gaps with Teichman (1985) older and more detailed account of the definition of a person.

Foster and Herring (2017a) outlined two general approaches to the definition of person. The first of these is the person as a member of the human species. In the language of Gallie (1955), this is the archetypal "exemplar" of personhood, from which all other uses derive (in Western scholarship at least). Certainly, the common language use of the word person is synonymous with human being, a fact exemplified by one of the Oxford English Dictionary definitions of person as "An individual 
human being: a man, woman, or child" (OED online). This definition has been defended as a natural bias in favour of human beings (Williams 2006), but has also been criticised by animal rights theorists and activists as a form of speciesism (See Singer 2009; Francione 2008). For Foster and Herring (2017a), such criticism is founded on the argument that membership of a species is not morally relevant and should not confer moral status.

The second broad category is where much of the contemporary action is. This category designates persons as those with certain mental capabilities. The obvious conflict is over which capabilities are deemed morally relevant—with major candidates including consciousness, self-interest, cognition, rationality and self-awareness-and who exactly possesses these capabilities. An influential example from the philosophical literature is provided by Locke's definition of a person as "A thinking intelligent being that has reason and reflection and can consider itself as itself" (Locke 1825, p. 225). This privileging of reason and self-consciousness is also found in numerous theological explications of person (Teichman 1985, pp. 179-81) and has persisted within Western philosophical thinking to the modern day. ${ }^{1}$ Historically, both of these categories have almost entirely overlapped on the concept of human being = person. Both have underpinned the legal sense of the concept of "person" as based on the notion of juridical rights (Teichman 1985, p. 180).

However, as an essentially contested concept ${ }^{2}$, the boundaries of personhood are not fixed. Most notably, the boundaries of the mental capacities category have been widened by animal theorists arguing for personhood on the basis of the capacities of non-human animals. There are numerous examples of this, including the capacities of non-human animals for intelligence, self-interest, and communication (see Bekoff 2000; Francione 2008). Scholars have also extended the mental capacity argument to the more corporeal considerations of personhood, including sentience, emotional capacity and the ability to suffer or feel pain (see Bekoff 2000; Singer 1975). This has been criticised by some scholars, most notably Plumwood (see Plumwood 1999), for being an extension of an essentially human category to non-human others based on traits they share with humans. In recent years, such extensions have led to attempts to grant juridical personhood to non-human animals, with varying degrees of success (Wise 2010). ${ }^{3}$ Even more recently, Puleo (2019) has taken this approach with plant personhood, attributing to plants all of his six (predetermined) characteristics of personhood (agency, sentience, perception, consciousness, communicability and contractibility).

Both of these broad approaches to personhood are essentially founded on the human being archetype. Marder's claim that plant personhood involves a human-centred projection onto plants would have some basis were such an approach to be employed. However, it is important to note here that in my book, Plants as Persons, I reject such approaches. Instead, I explore a broad concept of personhood based on relationship, which aligns better with Foster and Herring (2017b) relational approach to personhood. For Foster and Herring (2017b), the basic relational nature of the self means that moral worth is not to be found in individual capacities or in the membership of a species, but within relationships. That is, beings are conferred a moral status within the reciprocal nature of a relationship. For them, this problematises the question "Is so and so a person?", because we can only conceive of moral status in the context of relationships and corporeal interaction, rather than on an intellectual calculation of mental capacities. ${ }^{4}$

1 For a good example see Dennett (1988) “Conditions of Personhood": rationality, consciousness and intentional predicates, the attitude or stance taken towards something, reciprocity, verbal communication, and self-consciousness.

2 See (Gallie 1955; Stuckey 2010).

3 This approach can be contrasted with recent legal developments in Aotearoa New Zealand in which personhood has been granted to rivers (Whanganui River) and ancestral lands (Te Urewera) within the context of Māori settlement negotiations. While the legal bases for this recognition of personhood are complex (and far beyond the realm of this paper), it is worth noting that these are more aligned to a relational ethic. Indeed, the Background (s3) to the Te Urewera Act 2014 recognises that "Te Urewera has an identity in and of itself, inspiring people to commit to its care."

4 It is interesting that Dennett also partially recognises this by holding the view that "whether something counts as a person depends in some way on an attitude taken toward it, a stance adopted with respect to it." (Dennett 1988, p. 177). 
It is into this broadly relational approach to personhood that animist cultures would most comfortably fit. To both reject Marder's claims of "animist mentalities" projecting human purposes and goals and to lay bare the foundations of my own approach to plant personhood, I wish to briefly outline a body of scholarship in anthropology and religious studies that has sought to re-appraise the phenomenon of animism.

\section{Animist Mentalities}

Catalysed by the work of Irving Hallowell with the Ojibwa in the 1960s, there has been a concerted body of work in anthropology and religious studies to re-appraise the term animism from Tylor (1920, p. 425) portrayal of animism as "the deep-lying doctrine of Spiritual Beings" which "I propose here, under the name Animism." Tylor took his term from the 17th Century chemist and physician Georg Ernerst Stahl and developed a theory of a "belief in spirits" based on second-hand accounts of the lives of indigenous peoples regarded (as was common at the time) as "primitive". Key to Tylor's view of animism was that such peoples held a concept of the "soul", which was "a thin unsubstantial human image ... able to enter into, possess, and act in the bodies of other men, of animals, and even of things" (Tylor 1920, p. 429). For Tylor, the nature of this soul in plants extended beyond the Aristotelian plant soul (conferring the capacity for growth), which is "not unnaturally ... ascribed" to become more fully identified with the souls of animals, conferring sentience and mind (Tylor 1920, p. 475). Tylor's view of such a worldview is characterised throughout his work Primitive Culture as "savage", "crude" and "backward". Bird-David (1999, p. 69) points out that in holding such a view, the "primitives" were regarded as "doubly mistaken": mistaken about the existence of a "ghost soul" in humans and mistaken about the projection of this soul into non-human beings. The animist is thus like a child, projecting a false understanding of being, unable to tell the difference between the animate and the inanimate (Bird-David 1999, p. 69). Like Marder, Tylor connected this naïve perception of a "miraculous" plant soul with a similarly naïve "veneration" of the plants in question. For Tylor "the practice of tree-worship involves notions more or less closely coinciding with that of tree-souls" (Tylor 1920, p. 476). ${ }^{5}$

This Tylorian view of animism, to which Marder closely aligns himself, is founded on what Bird-David (1999, p. 68) calls "modernist" ontological dualisms, the dualisms explored by Plumwood (2002) being at the heart of destructive Western hyper-separation from the natural world: mind/body, soul/body, human/nature, amongst others. As Stuckey (2010, p. 188) neatly summarised, "By defining animism as focused on the immaterial side of a material-immaterial split, Tylor had firmly locked a Western epistemological frame onto perceptions of others' traditions." The obvious problem with such a view is that these animist traditions do not subscribe to these dualistic ontological categories.

The work of Irving Hallowell with the Ojibwa of North America fundamentally challenged this ontological schism. Hallowell (1960) recognised the concept of a person that was not categorically identified with human beings as being central to the worldview of the Ojibwa. He also recognised that such a radical shift in perspective was required to present an "accurate description" of the way humans in an animistic society relate to the world around them. For Hallowell (1960, p. 21):

The significance of these differences in perspective may be illustrated in the case of the Ojibwa by the manner in which the kinship term 'grandfather' is used. It is not only applied to human persons, but to spiritual beings who are persons of a category other than human.

The person category does not begin with a human exemplar or archetype. It is not a fundamentally human category. It is not a category based on an extension of the human. Instead person is an

5 James Frazer connected the presence of the separable plant soul with a notion that this led to the worship of plants. In a discussion of rituals involving rice, he asserted that "on this theory or myth of the plant-soul is built the whole worship of the cereals" (Frazer 1922, p. 414). Installed with a separable, animating soul, Frazer also saw "tree worship" as ubiquitous, dedicating three chapters of The Golden Bough to describing an array of practices that he argued to be evidence of this. 
overarching category of being. For Detwiler (1992, p. 239) "The category person applies to anything that has being, and who is therefore capable of relating." This category includes subcategories of persons, including human and non-human. Hallowell's shorthand for these subcategories is "other-than-human persons", a concept that has catalysed the renewed scholarship of animist traditions. Hallowell (1960) gave a number of concrete examples of such other-than-human persons, in Ojibwa culture, including the sun, the winds and rocks.

Bird-David (1999, p. 71) noted that Hallowell's contribution to the study of animism was transformative, serving to "free the study of animistic beliefs and practices from modernist person concepts" and the notion that these were erroneous. Yet, she proposed the term "superpersons" (Bird-David 1999, p. 68) rather than "other-than-human" persons "to avoid the possible implication that humanity is somehow definitive of personhood" (Harvey 2005, p. 20). Harvey (2005, p. 20) however, has defended Hallowell's conception of personhood.

Hallowell's phrase is rooted in understandings of ontological similarity rather than difference and does not assume that any particular kind of person is definitively 'ordinary'. Implicitly at least, it acknowledges the priority of close relationships over more distant ones. From a tree's point of view there might be 'tree persons' and 'other -than-tree persons', but Hallowell is a human addressing humans so 'other-than-human' remains useful.

Detwiler (1992, p. 239) makes a similar point in his discussion of the Oglala Lakota people:

Humans, or "two-leggeds" are only one type of person. Humans share their world with Wakan and non-human persons, including human persons, stone persons, four-legged persons, winged-persons, crawling-persons, standing-persons (plants and trees), fish-persons, among others.

Animists then are "people who recognise that the world is full of persons, only some of whom are human, and that life is always lived in relationship with others" (Harvey 2005, p. xi). Contrary to Marder's assertions, their concern is not with projecting or worshipping some dualistic, miraculous, immaterial soul (either in plants, animals or rocks), but relating to other persons, including non-humans, "as proper persons" (Descola 1992, p. 115). Like for Foster and Herring, scholars of animism have argued that it is through this act of relating that beings are brought into personhood. Hallowell (1960, p. 24) recounted a now famous story, which helps to explain how this may work.

Since stones are grammatically animate, I once asked an old man: Are all the stones we see about us here alive? He reflected a long while and then replied 'No! But some are.'

This qualified answer made a strong impression on Hallowell. He regarded the Ojibwa other-than-human person categories as not attributing "living souls to inanimate objects such as stones" or to being part of a "consciously formulated theory about the nature of stones" (Hallowell 1960, p. 24). Rather, "the Ojibwa recognize, a priori, potentialities for animation in certain classes of objects under certain circumstances ... The crucial test is experience" (Hallowell 1960, p. 24). The Ojibwa's openness to the potentialities of the natural world keeps open the possibilities for other-than-human persons that our modernist world view can so easily close off.

Drawing strongly on Hallowell, Bird-David (1999) described the concept of personhood among the Nayaka (an indigenous people of India) in which a person is one who is in a kinship relationship, not necessarily based on genealogy, mythology or biology, but through the situated act of sharing and relating. Again, as for the Ojibwa, this is not a mental representation of the nature of beings that is "applied to the world" (Bird-David 1999, p. 73). The Nayaka constitute their own personhood by producing and re-producing sharing relationships with surrounding beings and "as and when and because they engage in and maintain relationships with other beings, they constitute them as kinds of person: they make them "relatives" by sharing with them and thus make them 
persons" (Bird-David 1999, p. 73). Nayaka work toward relating to other-than-humans and are attentive to mutual behaviours in these other beings. In the case of plants, Bird-David echoed Kohák (1993) "speaking with trees", presenting this as "the epitome of Nayaka animistic epistemology" (Harvey 2005, p. 21).

'Talking' is shorthand for a two-way responsive relatedness with a tree-rather than 'speaking' one-way to it, as if it could listen and understand. 'Talking with' stands for attentiveness to variances and invariances in behavior and response of things in states of relatedness and for getting to know such things as they change through the vicissitudes over time of the engagement with them. (Bird-David 1999, p. 77)

Unlike in our categorisation above, Nayaka do not recognise a category of persons circumscribed by a certain set of a priori mental capacities. The stance of relating to other beings in the world is a foundation for knowing the world. Bird-David's re-visitation of animism stresses this relational epistemology, one in which knowing:

Grows from and is maintaining relatedness with neighbouring others. It involves dividuating the environment rather than dichotomizing it and turning attention to "we-ness," which absorbs differences, rather than to "otherness," which highlights differences and eclipses commonalities. Against "I think, therefore I am" stand "I relate, therefore I am" and "I know as I relate". (Bird-David 1999, p. 78)

This concept of "we-ness" and a focus on interrelation rather than difference is an integral part of animist conceptions of personhood. Bird-David (1999, p. 77) stated that non-human persons are made by human beings through acts of relating in which they are attentive to the behaviours of other beings. Put another way, other-than-humans are conferred moral status within a kinship relationship (genealogical or otherwise). In Nayaka culture, this relational epistemology model is very much immediate, being "concerned with engaging particular beings, which particular Nayaka meet, at a particular time and place." (Naveh and Bird-David 2013, p. 35). Nayaka are concerned with specific situations, rather than universalisms. If the attentiveness to beings collapses, so does the recognition of personhood (Naveh and Bird-David 2013).

\section{Ancestors and Attributes}

As Harvey (2013, p. 1) points out, "Animism is a hard-working word. It identifies a range of interesting phenomena but also labels several distinct ways of understanding such matters." Another approach to personhood is through ancestral, genealogical, biological, myth-bound, kinship relationships. As notions of genealogical kinship have been influential on my understanding of plant personhood, I wish to also outline such approaches here. Unfortunately, a full consideration would fill a whole monograph, so a few concise examples will have to suffice.

Across a number of animistic indigenous cultures, shared kinship is genealogical in nature, with humans and other beings sharing common, Earth-born, ancestry. As Whitt et al. (2003, p. 6) pointed out, "The nature of a genealogy is such that individuals cannot appear in it without thereby assuming relational ties to all others within the genealogy." The genealogical kinship between plants, animals, humans, rocks, etc., forms the basis of what Salmón calls a "kincentric ecology" (Salmón 2000) in which other-than-humans are brought into relationships of care and respect.

In Aotearoa, Māori people tell a creation story that creates a genealogical kinship, whakapapa, between all earthly beings. In the mythical Māori homeland, Hawaiki, the Sky Father Ranginui and the Earth Mother Papatūānuku were "lovers locked in an age-long embrace, during which they had many children" (Henare 2001, p. 202). The children of these initial Māori gods are the ancestors of all the beings in the world, including plants, rocks, seas, winds, animals and human beings. All then share whakapapa from Papatūānuku and Ranginui and from Tāne, the god of the forest, whose actions created the Earth. All beings on the Earth, including rocks, animals, humans, waters and plants, are 
held by kinship relationships. In the case of plants, for the great Māori weaver Erenora Puketapu-Hetet, the harakeke (flax) "is a descendant of the great god Tane-mahuta ... [and] today's Maori are related to harakeke and all the other plants, Tane is their common ancestor" (quoted in Whitt et al. 2003, p. 5).

In neighbouring Aboriginal Australia, there is a "multiplicity of types of totems", which are formed through multiple lines of descent, including matrilineal totems, which create relationships that "open outward to plants, animals, the elements and seasonality" (Rose 2013, p. 140). These kinship relationships are complex and crosscutting. Ultimately, they stem from the ever-present "everywhen" known commonly as the Dreaming. ${ }^{6}$ Aboriginal myths tell of Dreaming beings who walked the Earth and created the country. These beings are ancestral to all components of the natural world and "from them it is possible, and indeed imperative, to trace kinship among the things of the world" (Rose 1996, p. 29). An example of such a story is that of the red lily (Nelumbo nucifera) in the country of the Ngulugwongga in the Daly River region of northern Australia. The Dreaming ancestor Yilig-moi-indih or "Red Lily Woman" came across the country carrying red lily roots, which she planted in the ground as she went (Berndt et al. 1989). With a shared origin in the Dreaming, the plants share kinship with human beings. From this basis:

For many Aboriginal people, everything in the world is alive, animals,

trees, rains, sun, moon, some rocks and hills, and all people are conscious.

... All have a right to exist, all have their own places of belonging, all have their own Law and culture. (Rose 1996, p. 23)

In these kinship relationships, other-than-humans are recognised as having what has come to be known in some disciplines as "relational autonomy". ${ }^{7}$ They are known as relations, but as beings who have their own lives, their own perspectives and ways of doing. At least in part, through these kinship relationships, they are known as persons. Therefore, distinct from Bird-David's description of the Nayaka, in those cultures that have kinship systems that include other-than-humans, these help ground the situated, specific relationships that include other-than-humans as persons.

In many cultures, the transmission of this genealogy and ancestral knowledge, through myths and stories, helps people to learn about their kinship relationships with, and the capacities of, other-than-humans ${ }^{8}$. In his work with the Ojibwa, Hallowell recognised that "true" stories (myths) reinforce the situated, dialogical relationships that can manifest in communication, both human and other-than-human.

The conceptual reification of Flint, the Winds and the Sun as other-than-human persons exemplifies a world view in which a natural-supernatural dichotomy has no place. And the representation of these beings in 'true' stories reinforces their reality by means of a cultural device which at the same time depicts their vital roles in interaction with other persons as integral forces in the functioning of a unified cosmos. (Hallowell 1960, p. 29)

What then of the capacities of the other-than-human persons represented in such stories? In his treatment of a multiplicity of animisms, Graham Harvey asked some searching questions of how person-person encounters work in practice and what they may tell us of the characteristics of other-than-human persons. In particular, Harvey asks: "How does an animist know when to act in ways appropriate to 'I-Thou' rather that 'I-it' encounters?" That is, when being attentive to kinship-bound relationships (either situated, genealogical or both), "what signs of life and personhood might an animist adduce?" (Harvey 2005, p. 99). These are powerful questions that bring us

\footnotetext{
The term "everywhen" was coined by (Stanner 1979) to try to express the fact that the Dreaming cannot be fixed in time. See (Mackenzie and Stoljar 2000).

See (Hall 2019).
} 
to a tension at the core of other-than-human personhood and highlight the interplay between an interrelational stance, its attentiveness to the behaviours of non-humans, and the observed capacities of other-than-human persons.

There is no definitive list of characteristics that entail personhood, but are there indications that give animists an idea that they are on the right track? Harvey (2005, p. xvii) definition of personhood relates that:

Persons are volitional, relational, cultural and social beings. They demonstrate agency and autonomy with varying degrees of autonomy and freedom.

Persons are also recognised as living beings, with "their own perspective, and with the ability to communicate in their own way" (Hall 2011, pp. 105-106). Persons display the commonalities of living beings, such as ageing, disease, decay and death. Persons also tend to be active, with other accounts of the general characteristics of personhood including sentience, will and even consciousness (see Detwiler 1992; Rose 1996). Personhood is also associated with awareness, and persons have their own perspective (Harvey 2005). In this context, Aboriginal elder Bill Neidjie succinctly described the awareness and perspective of plant persons in Gagudju country:

Tree ... he watching you.

You look at tree, he listen to you.

He got no finger, he can't speak.

But that leaf...

he pumping, growing, growing in the night.

(Neidjie 1985, p. 52)

An open, relational stance, an attentiveness to the behaviour and characteristics of livings beings, an emphasis on connection rather than separation and the recognition and re-telling of genealogical kinship are all aspects of animistic approaches to personhood that have influenced and informed my understanding of plant personhood. They provide a strong counter to Marder's claims of animist projection and naïve veneration.

\section{From Personhood to Flourishing}

From this brief re-visitation of animism, we turn to Marder's second, related, observation that:

The problematic assumption that the concept of personhood can be extended to plants underpins Matthew Hall's recent book, Plants as Persons: A Philosophical Botany ... (Marder 2013, p. 37)

The exploration of animism above has helped lay the ground work for a number of responses that I wish to make. The first is that the animist person category on which I draw is not archetypally human, so there is no need to extend it to other-than-humans. The category includes all types of beings capable of relating, and subcategories of person are acknowledged. Although attributes of personhood can be recognised and can inform behaviour, unlike for some animal rights theorists such as Peter Singer, these do not constitute a pre-agreed set of mental capacities that qualify a plant for personhood. As such, it is not, and cannot be, a concept that can be violently projected onto the natures of other-than-human beings. Personhood emerges from attentiveness to their nurturing. Personhood emerges from relationships of kinship and sharing. Personhood emerges from "talking with" the trees, not talking for them.

A second response is that the concept of plant personhood is far from problematic. It emerges from an attentive, inclusive approach to plant life that seeks to relate to beings in the world, and in doing so recognizes a range of animate characteristics: including life, communication, agency, autonomy, 
sentience and volition. Such plant characteristics are increasingly supported by an ever-growing body of empirical observations in the plant sciences. This relational approach privileges and seeks to emphasise connection to beings in the face of morphology and physiology that are radically different from the human. In a world in which human societies have constructed and emphasised difference in order to justify domination (Plumwood 2002), the ethic of connection is a powerful countervailing force.

Another response is that, although it may appear so from the title, the concept of personhood does not underpin my attempt to argue for the moral consideration of plants. In Plants as Persons, I do not argue that plants are contiguous with human beings, nor do I argue that plants display a pre-defined set of mental capacities that qualify them for personhood (an archetypally extended human personhood). I clearly draw on the general principles of a relational personhood gleaned from the new approach to animist phenomena outlined above; however, I use this inspiration in combination with other key concepts to challenge my own view of plant life and to construct my own approach to plant moral consideration. I do this in an attempt to avoid appropriating other knowledge systems and to ensure that my approach to moral consideration has currency in my Western context. A brief summary of this approach must suffice.

Against the backdrop of a human hyper-separation from nature founded on hierarchical ontological dualisms such as nature/culture, mind/matter, as the alterity of plants, their "absolute otherness" is manifestly apparent. Hallé (2002) characterises plant form as "alien" to human beings. Although few would contest the fact that plants have radical morphological differences with humans, I reject the approach of Hallé (as I reject the approach of Marder) that better relationships will come through emphasising and deepening our appreciation of such otherness. Instead, I outline a philosophy that seeks affinity with plants and deliberately takes a relational, inclusive stance, which emphasises our connections, inspired in part by those indigenous animist cultures (but also Jain and Buddhist traditions) that have created relationships in the face of the clear and non-subsumable alterity of plants. On this basis, I seek to undercut the Aristotelian hierarchy of nature, which positions plants as passive beings, by outlining those capacities of plants described when humans (including indigenous animists, Jains and some Buddhists) are attentive to their natures, including sentience, intelligence, agency and volition. I support this by charting the ever-growing body of empirical observations in the plant sciences that are uncovering the intelligent, volitional behaviour of plants, which has since moved on to discussions of plant cognition and sentience (Calvo et al. 2017). ${ }^{9}$

Equipped with this understanding of plant behaviour, "Instead of trying to prove the existence of criteria, I base the recognition of plants as morally considerable (as persons) upon the ground of Erazim Kohák's philosophical ecology ... " (Hall 2011, p. 158). In Kohák's view "manners of speaking" are "modes of interacting with reality" "which render our world meaningful and guide our actions therein" (Kohák 1993, p. 385). The choices between these manners of speaking matter as they can lead to vastly different ends. In the context of a contemporary ecological crisis, Kohák insisted that we have a choice between "treating trees as raw materials or treating them with respect" (Kohák 1993, p. 383). The argument that underpins Plants as Persons is that based on the current evidence of their characteristics and abilities and their well-established genealogical kinship with human beings, it is more appropriate in our "manner of speaking" to accord plants moral status, to relate to them as persons, than to treat them as an inexhaustible supply of "raw materials" here only for human ends.

Relating to plants as persons does not entail that we must eschew all use of plants in our daily lives. We rely almost entirely on plants for our food, medicines and shelter. It is not possible for human beings to live without killing at least some plants. Where some traditions (including Tibetan Buddhism and Jainism) have sought to deny or to minimise this violence, the recognition of plants as persons acknowledges this fact of earthly life. In doing so, it counters the real philosophical violence

9 This evidence is of great interest to the history and philosophy of science, as it is beginning to overturn the "modernist" enlightenment ontology from which it is derived. (I owe this point to an anonymous reviewer of this manuscript). 
against plants, the banal violence outlined by (Yusoff 2012), which involves denying their own lives and presence. Using the terms of Mikhail Bakhtin, I characterize this as a monological stance. For Bakhtin, monologue does not recognize the voice or presence of the other; "Monologue is finalized and deaf to the other's response, does not expect it and does not acknowledge it any decisive force. Monologue manages without the other ... " (Bakhtin 1984, p. 293).

In contrast to a human-centred monologue, recognising and relating to plants as persons opens up the possibility of a dialogue in which distinct "voices" and presences are heard and amplified. This dialogical attentiveness to the presence, to the lives and ways of plants in the world, is at the heart of my understanding of plant personhood. ${ }^{10}$ In the language of Bird-David and Kohák, this is "talking with" or "speaking with" plants. The lesson from animist cultures is that such a dialogue must be situated and embodied in care relationships with specific plants and plant communities. Therefore:

Allowing plant "voices" to be heard entails approaching plants with openness and allowing plants to flourish. Working for the benefit of plants is, therefore, a direct way to build more dialogical human-plant relationships, which ultimately result in moral consideration and action. As Deborah Rose explains, "A dialogical approach to connection impels one to work to realize the wellbeing of others ... The path to connection, therefore, does not seek connection, but rather seeks to enable the flourishing of others." (Rose 1999, p. 185; Hall 2011, p. 174.)

We circle back then to the relational approach to personhood. It is relatively easy to argue philosophically for plants as persons, but much harder to enact and realise plant personhood in the context of worldly relationships. One of the ways that I suggest we do such working for the benefit of plants and toward plant flourishing is through local ecological restoration, including actively and intentionally giving back space (i.e., land) for wild plant communities to flourish. I reiterate that call here, and do so in accordance with E.O. Wilson, who has argued that we need to set aside at least half of our planet for other-than-human purposes. In doing so, we must ensure that this does not lead to another hyper-separation of human/natures, in the search for a pure "wilderness" in which plant communities become removed from all human engagement and use. For relationships of care to be built, the priority must be for long-term restorative projects in places of human habitation or with a history of human domination. Hundreds of such projects already exist, from large-scale landscape restoration of the Florida Everglades, to wetland restoration in former industrial sites. For those of us who carry with us a Christian heritage that has traditionally denied personhood to plants, engaging with such projects carries the potential to take us from our position as the apex of a hierarchy of domination and move us towards a heterarchical position grounded in care and partnership with the other-than-human world. ${ }^{11}$ The recognition of plants as persons emerges then not through the violent projection of human purposes and goals as Marder insists, nor indeed in the pages of academic texts, but from working with, relating to and caring for a multitude of plants in collaborative projects of mutual benefit.

Funding: This research received no external funding.

Acknowledgments: My work on plant personhood would not have been possible without the incredible nurture and support provided by the late Deborah Bird Rose.

"When lilacs last in the dooryard bloom'd,

And the great star early droop'd in the western sky in the night,

I mourn'd, and yet shall mourn with ever-returning spring." Walt Whitman.

Conflicts of Interest: The author declares no conflicts of interest.

10 Intriguingly, the early Anglo-Norman and Old French etymology includes the notion of "presence" or "appearance" in the definition of person.

11 This potential is explored in depth by (Van Wieren 2013). 


\section{References}

Bakhtin, Mikhail. 1984. Problems of Dostoevsky's Poetics. Minneapolis: University of Minnesota Press.

Bekoff, Marc. 2000. Animal Emotions: Exploring Passionate Natures. BioScience 50: 861-70. [CrossRef]

Berndt, Ronald Murray, Catherine Helen Berndt, and Australia Council Literature Board. 1989. The Speaking Land: Myth and Story in Aboriginal Australia. Ringwood: Penguin Books.

Bird-David, Nurit. 1999. “Animism" Revisited: Personhood, Environment, and Relational Epistemology. Current Anthropology 40: S67-S91. [CrossRef]

Calvo, Paco, Vaidurya Pratap Sahi, and Anthony Trewavas. 2017. Are Plants Sentient? Plant, Cell E Environment 40: 2858-69.

Dennett, Daniel. 1988. Conditions of Personhood. In What Is a Person? Edited by Michael F. Goodman. Totowa: Humana Press, pp. 145-67.

Descola, Philippe. 1992. Societies of Nature and the Nature of Society. In Conceptualizing Society. Edited by Adam Kuper. London and New York: Routledge, pp. 107-26.

Detwiler, Fritz. 1992. "All My Relatives": Persons in Oglala Religion. Religion 22: 235-46. [CrossRef]

Foster, Charles, and Jonathan Herring. 2017a. Theories of Personhood. In Identity, Personhood and the Law. Edited by Charles Foster and Jonathan Herring. Springer Briefs in Law. Cham: Springer International Publishing, pp. 21-34.

Foster, Charles, and Jonathan Herring. 2017b. A Relational Account of Personhood. In Identity, Personhood and the Law. Edited by Charles Foster and Jonathan Herring. Springer Briefs in Law. Cham: Springer International Publishing, pp. 35-42.

Francione, Gary Lawrence. 2008. Animals as Persons: Essays on the Abolition of Animal Exploitation. New York: Columbia University Press.

Frazer, James George. 1922. The Golden Bough; a Study in Magic and Religion. New York: The Macmillan Company.

Gallie, Walter Bryce. 1955. Essentially Contested Concepts. Proceedings of the Aristotelian Society 56: 167-98. [CrossRef]

Hall, Matthew. 2011. Plants as Persons a Philosophical Botany. SUNY Series on Religion and the Environment; Albany: State University of New York Press.

Hall, Matthew. 2019. The Imagination of Plants: A Book of Botanical Mythology. Albany: State University of New York Press.

Hallé, Francis. 2002. In Praise of Plants. Portland: Timber Press.

Hallowell, A. Irving. 1960. Ojibwa Ontology, Behavior, and World View. In Culture in History: Essays in Honor of Paul Radin. Edited by Stanley Diamond. New York: Columbia University Press.

Harvey, Graham. 2005. Animism: Respecting the Living World. New York: Columbia University Press.

Harvey, Graham. 2013. Introduction. In The Handbook of Contemporary Animism. Edited by Graham Harvey. Durham: Acumen, pp. 1-12.

Henare, Manuka. 2001. Tapu, Mana, Mauri, Hau, Wairua: A Māori Philosophy of Vitalism and Cosmos. In Indigenous Traditions and Ecology: The Interbeing of Cosmology and Community. Edited by John Grim. Cambridge: Harvard University Press, pp. 197-221.

Kohák, Erazim. 1993. Speaking to Trees. Critical Review 6: 317-88. [CrossRef]

Locke, John. 1825. An Essay Concerning Human Understanding. London: Tegg.

Mackenzie, Catriona, and Natalie Stoljar. 2000. Relational Autonomy: Feminist Perspectives on Autonomy, Agency, and the Social Self. Oxford: Oxford University Press.

Marder, Michael. 2013. Plant-Thinking: A Philosophy of Vegetal Life. New York: Columbia University Press.

Marder, Michael. 2013. Is It Ethical to Eat Plants? Parallax 19: 29-37. [CrossRef]

Naveh, Danny, and Nurit Bird-David. 2013. Animism, conservation and immediacy. In The Handbook of Contemporary Animism. Edited by Graham Harvey. Durham: Acumen, pp. 27-37.

Neidjie, Bill. 1985. Kakadu Man. New South Wales: Mybrood.

Plumwood, Val. 1999. Ecological Ethics from Rights to Recognition: Multiple Spheres of Justice for Humans, Animals and Nature. In Global Ethics and Environment. Edited by Nicholas Low. London: Routledge, pp. 188-212.

Plumwood, Val. 2002. Environmental Culture: The Ecological Crisis of Reason. London: Routledge. 
Puleo, Thomas J. 2019. Incorporating Nonhuman Subjectivity into World Society: The Case of Extending Personhood to Plants. In Modern Subjectivities in World Society: Global Structures and Local Practices. Edited by Dietrich Jung and Stephan Stetter. Palgrave Studies in International Relations. Cham: Springer International Publishing, pp. 211-27.

Rose, Deborah Bird. 1996. Nourishing Terrains: Australian Aboriginal Views of Landscape and Wilderness. Canberra: Australian Heritage Commission.

Rose, Deborah Bird. 1999. Indigenous Ecologies and an Ethic of Connection. In Global Ethics and Environment. Edited by Nicholas Low. London: Routledge, pp. 175-87.

Rose, Deborah Bird. 2013. Death and grief in a world of kin. In The Handbook of Contemporary Animism. Edited by Graham Harvey. Durham: Acumen, pp. 137-477.

Salmón, Enrique. 2000. Kincentric Ecology: Indigenous Perceptions of the Human-Nature Relationship. Ecological Applications 10: 1327-32.

Singer, Peter. 1975. Animal Liberation: A New Ethics for Our Treatment of Animals. New York: Random House.

Singer, Peter. 2009. Speciesism and Moral Status. Metaphilosophy 40: 567-81. [CrossRef]

Stanner, William Edward Hanley. 1979. White Man Got No Dreaming: Essays 1938-1973. Canberra: Australian National University Press.

Stuckey, Priscilla. 2010. Being Known by a Birch Tree: Animist Refigurings of Western Epistemology. Journal for the Study of Religion, Nature \& Culture 4: 182-205.

Teichman, Jenny. 1985. The Definition of Person. Philosophy 60: 175-85. [CrossRef]

Tylor, Edward Burnett. 1920. Primitive Culture: Researches into the Development of Mythology, Philosophy, Religion, Language, Art, and Custom. London: Murray.

Van Wieren, Gretel. 2013. Restored to Earth: Christianity, Environmental Ethics, and Ecological Restoration. Washington: Georgetown University Press.

Whitt, Laurie Anne, Mere Roberts, Waerte Norman, and Vicki Grieves. 2003. Indigenous Perspectives. In A Companion to Environmental Philosophy. Edited by Dale Jamieson. Hoboken: John Wiley \& Sons, Ltd., pp. 3-20.

Williams, Bernard. 2006. The Human Prejudice. In Philosophy as a Humanistic Discipline. Edited by Adrian William Moore. Princeton: Princeton University Press, pp. 135-52.

Wise, Steven M. 2010. Legal Personhood and the Nonhuman Rights Project Introduction. Animal Law 17: 1-12. Yusoff, Kathryn. 2012. Aesthetics of Loss: Biodiversity, Banal Violence and Biotic Subjects. Transactions of the Institute of British Geographers 37: 578-92. [CrossRef] 